\title{
ARC Definite Stent Thrombosis
}

National Cancer Institute

\section{Source}

National Cancer Institute. ARC Definite Stent Thrombosis. NCI Thesaurus. Code C119598.

Includes acute ischemic symptoms at rest, acute post ischemic ECG, positive biomarkers and pathological evidence. Definite stent thrombosis is considered to have occurred when there is either angiographic or pathological confirmation. Angiographic confirmation is the presence of a thrombus at coronary ang iography that originates in the stent or in the segment $5 \mathrm{~mm}$ proximal or distal to the stent, with the presence of at least 1 of 3 clinical criteria within a 48-hour time window: 1) acute onset of ischemic symptoms at rest; 2) new ischemic ECG changes that suggest acute ischemia; or 3) typical rise and fall in cardiac biomarkers. Pathological confirmation is evidence of recent thrombus within the stent determined at autopsy or via examination of tissue retrieved following thrombectomy. (Cutlip DE, Windecker S, Mehran R, et al. Clinical End Points in Coronary Stent Trials : A Case for Standardized Definitions. Circulation. 2007;115:23442351) 